\title{
A ground up approach to revegetation in the arid zone
}

\author{
G Christie Succession Ecology Pty Ltd, Australia \\ B Horner Succession Ecology Pty Ltd, Australia
}

AT Scanlon Succession Ecology Pty Ltd, Australia

J Lemon Succession Ecology Pty Ltd, Australia

B Williams Flinders Power, Australia

\begin{abstract}
Revegetation of mine sites in the arid zone is inherently challenging because of high costs, poor plant survival in harsh conditions, and difficulties in managing expectations of various stakeholders. A 'top down' approach to site revegetation uses predominantly mid-and upper-storey species and, in South Australia, typically involves planting of tubestock or line seeding and associated activities, such as watering and weeding. In contrast, a 'ground up' approach involves sowing a site with native seeds of colonising plants using a cropping methodology. A comparative analysis of three approaches to revegetation was conducted, these were: 1) a 'top down' approach using tubestock; 2) a 'top down' approach using line seeding; 3) a 'ground up' approach using agricultural spreading machinery (hereafter broadacre seeding) and native colonising species.

The performance of each approach was gauged against identified criteria for mine site closure in semi-arid and arid areas. The analysis showed that revegetation with 'top down' tubestock methods was least effective and the 'ground up' broadacre seeding most effective. Specific areas in which the 'ground up' approach outperformed the 'top down' approaches included increasing site stability, plant survivorship, vegetation structure (complexity), system function, decreasing weeds, cost and risk. Four case studies demonstrating the 'ground up' broadacre seeding technique are presented including the revegetation of two capped sites (a power station's ash dam and a waste infill site) and the conversion of two ex-agricultural sites to native vegetation areas. Broadacre seeding with native colonising species provides many benefits to site stability and productivity and is a cost-effective approach to broad-scale revegetation in the arid zone.
\end{abstract}

Keywords: arid zone, erosion, dust mitigation, native seed, revegetation, tubestock, succession

\section{Introduction}

Revegetation of mine sites in the arid zone is inherently challenging because of high costs, poor survival outcomes for plants in harsh conditions, and difficulties in managing expectations of various stakeholders. Traditionally, revegetation in South Australia has been conducted using a 'top down' approach where predominantly mid-and upper-storey species are returned to a site using tubestock planting or line seeding (Government of South Australia 2011; Natural Resources South Australia 2019a, 2019b; Trees for Life 2019). With these methods, many projects aspire to recreate original ecosystems. This thinking is represented in the Standards Reference Group (SER 2017) guidelines for ecological revegetation in Australia. However, it is increasingly apparent that it can be 'extraordinarily difficult' and 'not practically possible' to re-form 'destroyed' ecosystems (Bowman 2013). Because mine sites have vastly different biological and physiological characteristics to the original systems, novel or hybrid ecosystems have been proposed as suitable for their rehabilitation (Doley \& Audet 2013). In fact, Doley \& Audet (2013) promote the use of new combinations of species including native and non-native plants.

In contrast to traditional methods, a 'ground up' approach, floods a site with the seed of local native colonising species, which are adapted to the site conditions. This method is based on the theory of ecological succession (e.g. Clements 1916); it promotes self-sustaining ecosystems that increase in complexity and 
function with time. A natural increase in plant species diversity with time was demonstrated in a study by Haby (2017). In this study, a degraded chenopod shrubland area of semi-arid South Australia was direct seeded with seven mid- and late-successional species. These species persisted ten-years later; meanwhile, another 29 native species had also colonised the site. A 'ground up' approach would have prioritised those colonising species within the original seed mix.

In addition to differences in species assemblages used in 'top down' versus 'ground up' methodologies, there is a marked contrast in the delivery mechanism of each system. The 'top down' approach tends to involve planting of tubestock or direct seeding with a line seeder, promoting low plant densities. Activities associated with these methods include watering, weed management and 'thinning out' plants growing at inappropriately high densities (Natural Resources South Australia 2019a). While these approaches may be appealing to many managers and the public, they may not comprise the most appropriate revegetation approach. In contrast a 'ground up' approach uses colonising species applied using a cropping methodology, which allows rapid and broadacre application (flooding) of seeds into a site. Notably, the cropping methodology also allows for rapid dispersal of a broad range of seed types including grasses (e.g. Austrostipa species) and chenopods (light Maireana seeds and heavier Nitraria and Enchylaena seeds). This approach has few other associated activities, watering is not required nor is thinning out of plants; the rapidly growing and reproducing colonising species compete with weeds reducing the need for site management.

The objectives of this study were to demonstrate the effectiveness of the 'ground up' approach compared to a 'top down' approach for mine closure within a semi-arid to arid revegetation environment. A series of case studies demonstrating the 'ground up' methods in semi-arid areas and their outcomes are also presented.

\section{Methodology}

A comparative analysis of 'top down' and 'ground up' approaches was made for three revegetation methodologies:

1. 'Top down' approach using tubestock - native plants are grown in small pots or tubes in nurseries in ideal conditions (light and water); live seedlings are transported to the revegetation site and hand- or machine-planted directly into the ground, often with a fertiliser pellet and a tree guard. Watering of tubestock occurs at planting, follow-up watering regimes will be determined by individual projects. The immediate visual impact of plants and tree guards onsite can be particularly appealing to managers and other stakeholders (Figure 1).

2. 'Top down' approach using line seeding - line seeding is also referred to as direct seeding; typically, it involves sowing seeds in linear trenches spaced 4-5 $\mathrm{m}$ apart with V-blade machinery. Because species selection favours tree and large shrub species (e.g. Carr et al. 2007; Lance 2015; Australian Government 2019), germinants compete for light and resources; they grow tall, often without developing lateral branches, and may require thinning out (Natural Resources South Australia 2019a). The inter-line spaces can also harbour weeds and may need management (Figure 2).

3. 'Ground up' approach using agricultural spreading machinery, hereafter broadacre seeding - unlike line seeding, a broadacre direct-seeding approach spreads seed across the entire site at densities analogous with agriculture (i.e. Crettenden 2013); the site is effectively flooded with new seed. Species selection is crucial to this approach; it prioritises native colonising species that thrive with disturbance, tolerate challenging conditions, reproduce rapidly to replenish soil seedbanks and compete for space and resources with weeds, reducing the need for weed management (Figure 2). 


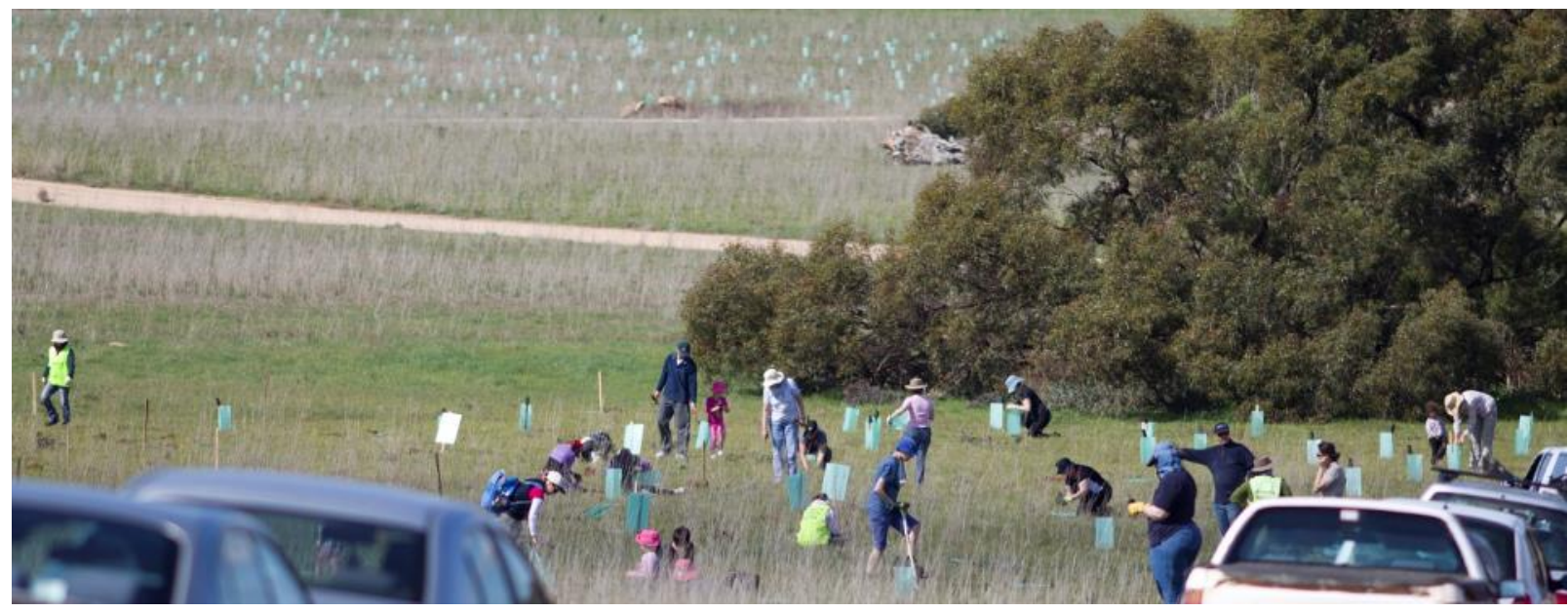

Figure 1 The 'top down' approach to revegetation using tubestock; the methodology has strong visual impact and is appealing to many managers and other stakeholders
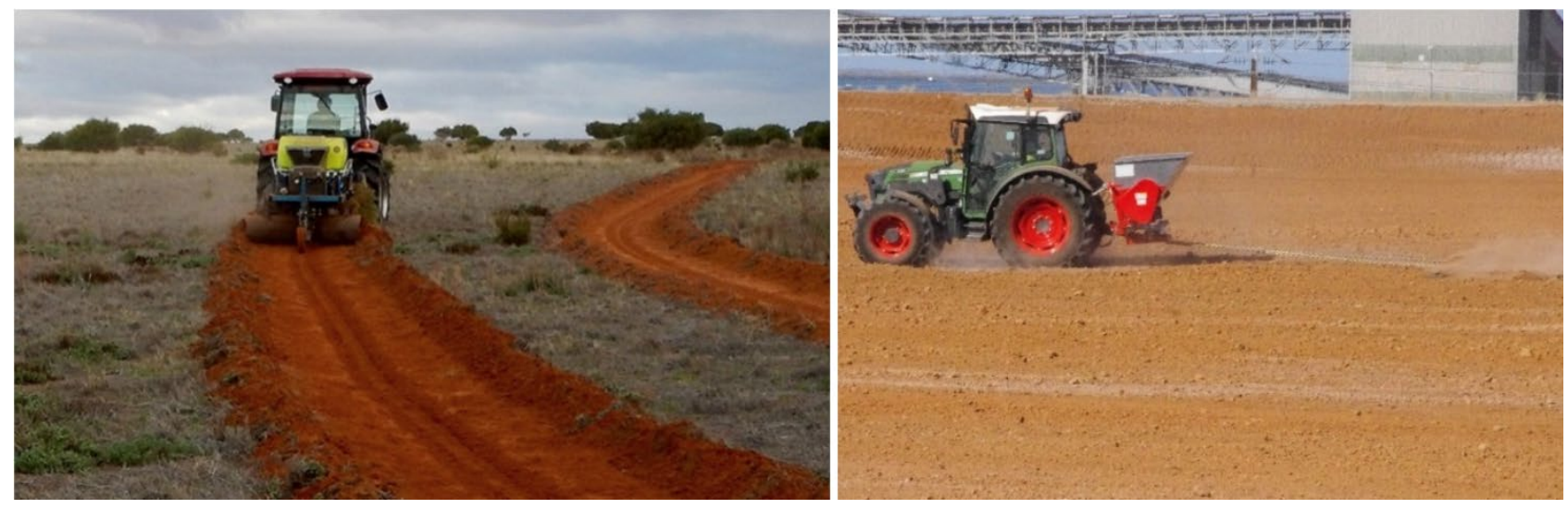

Figure 2 Revegetation methodologies that use direct seeding include line seeding with a V-blade (left; as promoted by Trees for Life's direct seeding materials) and broadcast cropping (right)

A comparative analysis of the three methods was made based on the authors' combined experience of over 60 years in the revegetation industry, including detailed knowledge of specific projects. The analysis was supported by the literature where possible; however, many groups do not publish details on survivability or costs associated with individual projects (Palma \& Laurance 2015), or reporting may be informal (e.g. community newsletters, promotional materials). Relative effectiveness of the techniques was based on identified objectives for mine site recovery within semi-arid to arid conditions, as such successful restoration would provide revegetation outcomes that:

- Stabilise the soil.

- Establish rapidly.

- Reduce or eliminate weed management.

- Create a system that is self-sustaining (renewing and resilient). 
In terms of quantifying performance against these objectives, each technique was gauged on achieving the associated attributes of success as detailed in Table 1.

Table 1 Identified objectives for arid mine site revegetation, and the attributes associated with success

\begin{tabular}{ll}
\hline Objective & Attributes of success \\
\hline Stabilise the soil & $\begin{array}{l}\text { Plants are tolerant to poor soil conditions, provide rapid soil cover to reduce } \\
\text { erosion; dense, low growth and leaf litter production creates favourable } \\
\text { microclimates for soil crust development and soil and seed capture }\end{array}$ \\
Establish rapidly & $\begin{array}{l}\text { Plants establish rapidly, they thrive with disturbance and have high survivability; } \\
\text { reproduction will be rapid. Plants respond opportunistically to environmental } \\
\text { conditions onsite }\end{array}$ \\
$\begin{array}{l}\text { Reduce weed } \\
\text { management }\end{array}$ & $\begin{array}{l}\text { Plants will be competitive, covering the soil quickly and reproducing rapidly to } \\
\text { replenish depleted seedbanks and compete with weeds } \\
\text { self-sustaining }\end{array}$ \\
$\begin{array}{l}\text { The system will develop rapidly, plants will reproduce successfully, ecosystem } \\
\text { functions return and complexity (species diversity) and resilience will increase } \\
\text { with time }\end{array}$ \\
\hline
\end{tabular}

\section{$3 \quad$ Results}

\subsection{Comparative analysis of 'top down' and 'ground up' methodologies}

The comparative analysis is available in Table 2. It demonstrates differences among the approaches and how tubestock and line seeding are unsuitable and slow (respectively) for revegetation in semi-arid and arid systems. Where risk is defined, it is based on the existing literature and authors' experiences with a range of projects, to gauge performance against the objectives articulated in Table 1. Broad trends in the relative performance of each technique are summarised in Figure 3. Tubestock methods were deemed least suitable for the revegetation of mine sites in semi-arid and arid regions, line seeding was moderately effective, and broad-scale seeding was most suitable. 


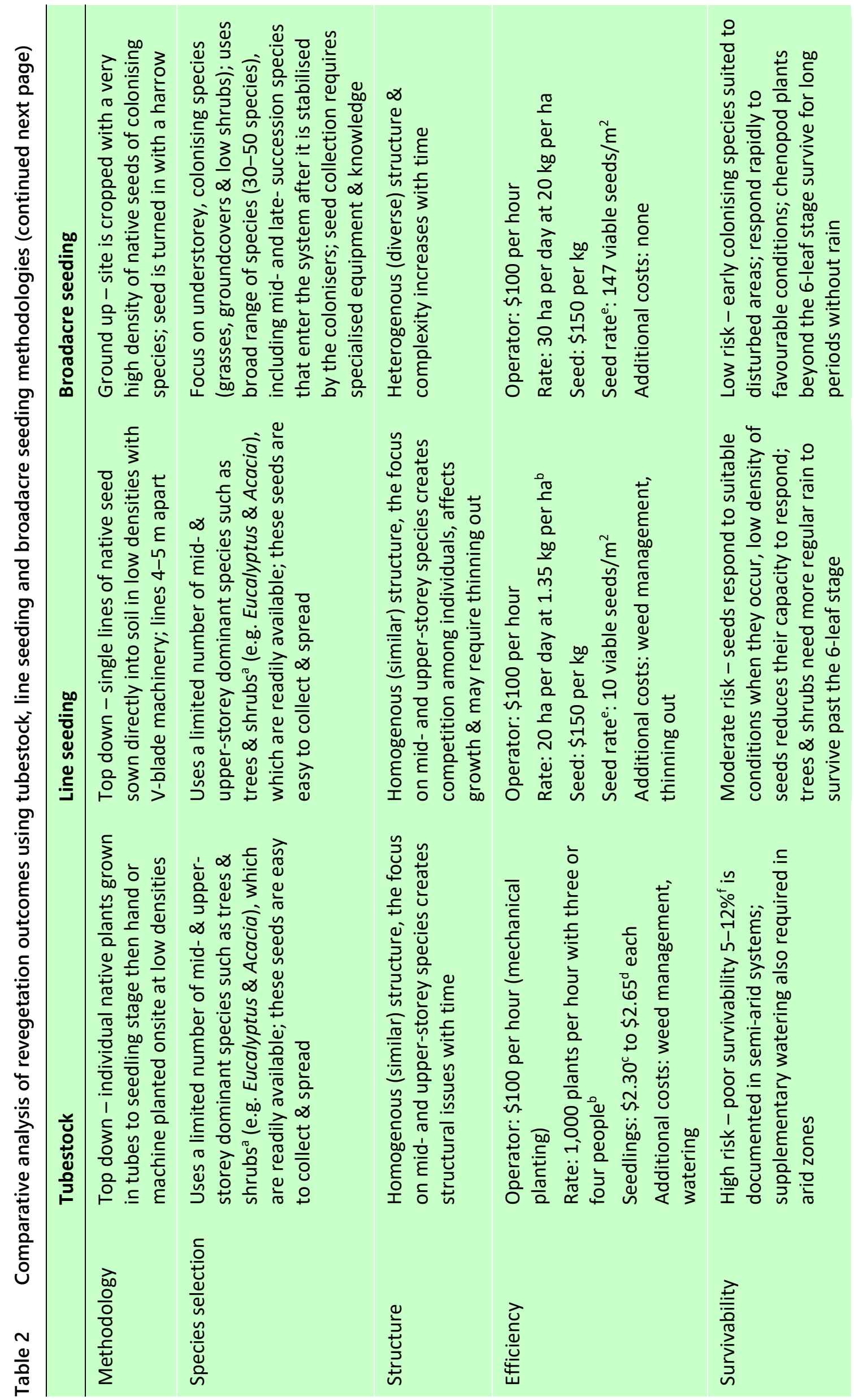




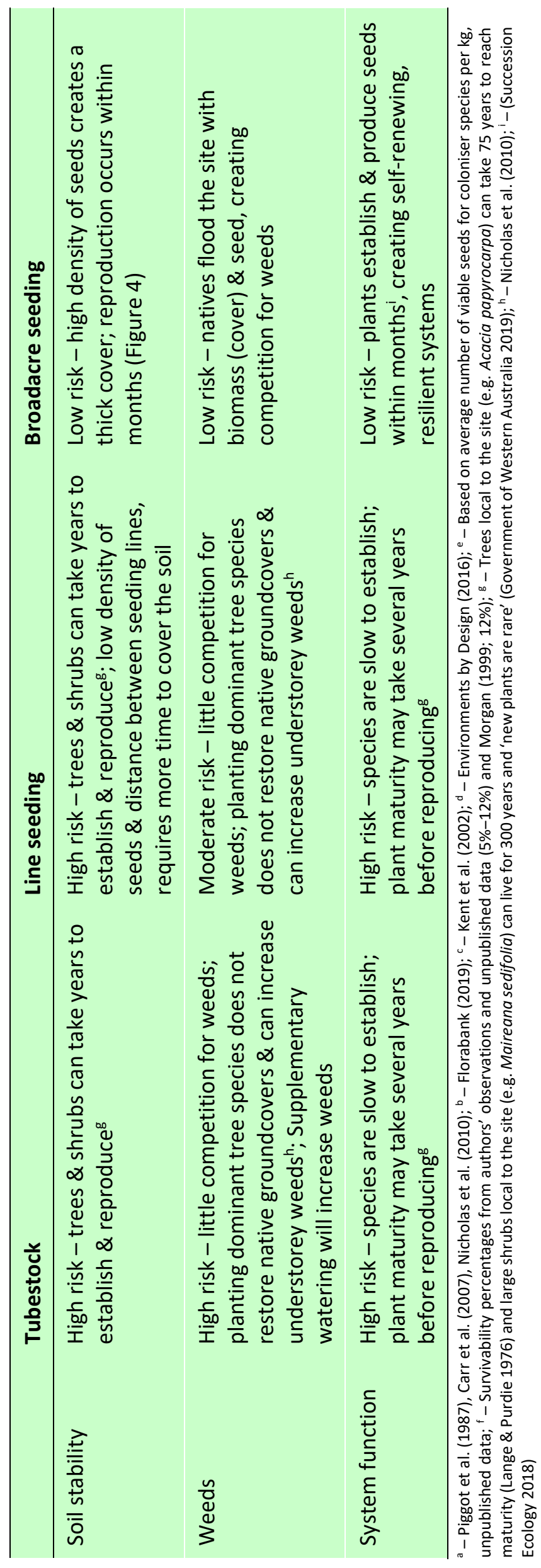




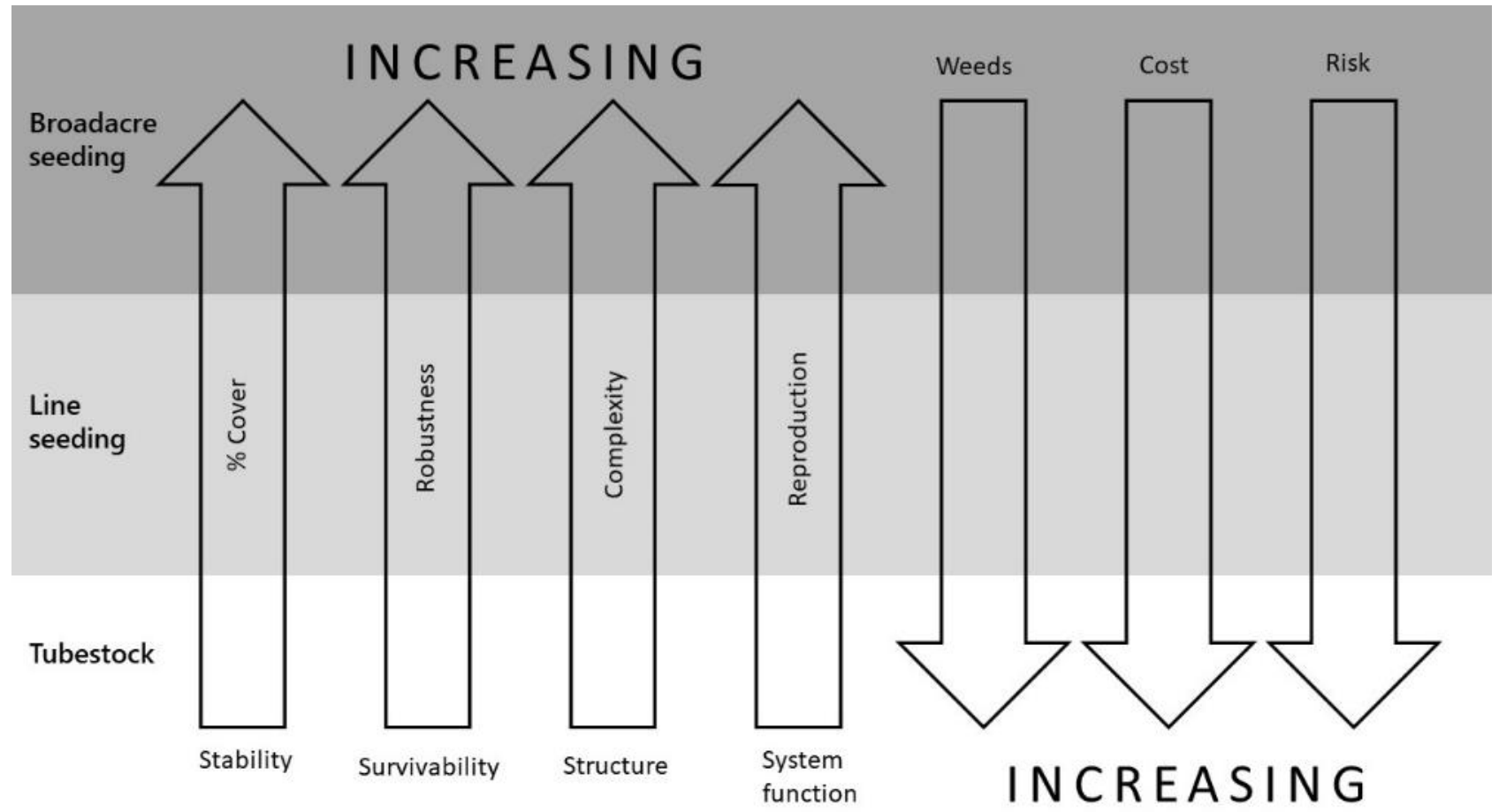

Figure 3 Graphic representation of broad trends in three approaches to mine site revegetation in semi-arid and arid systems

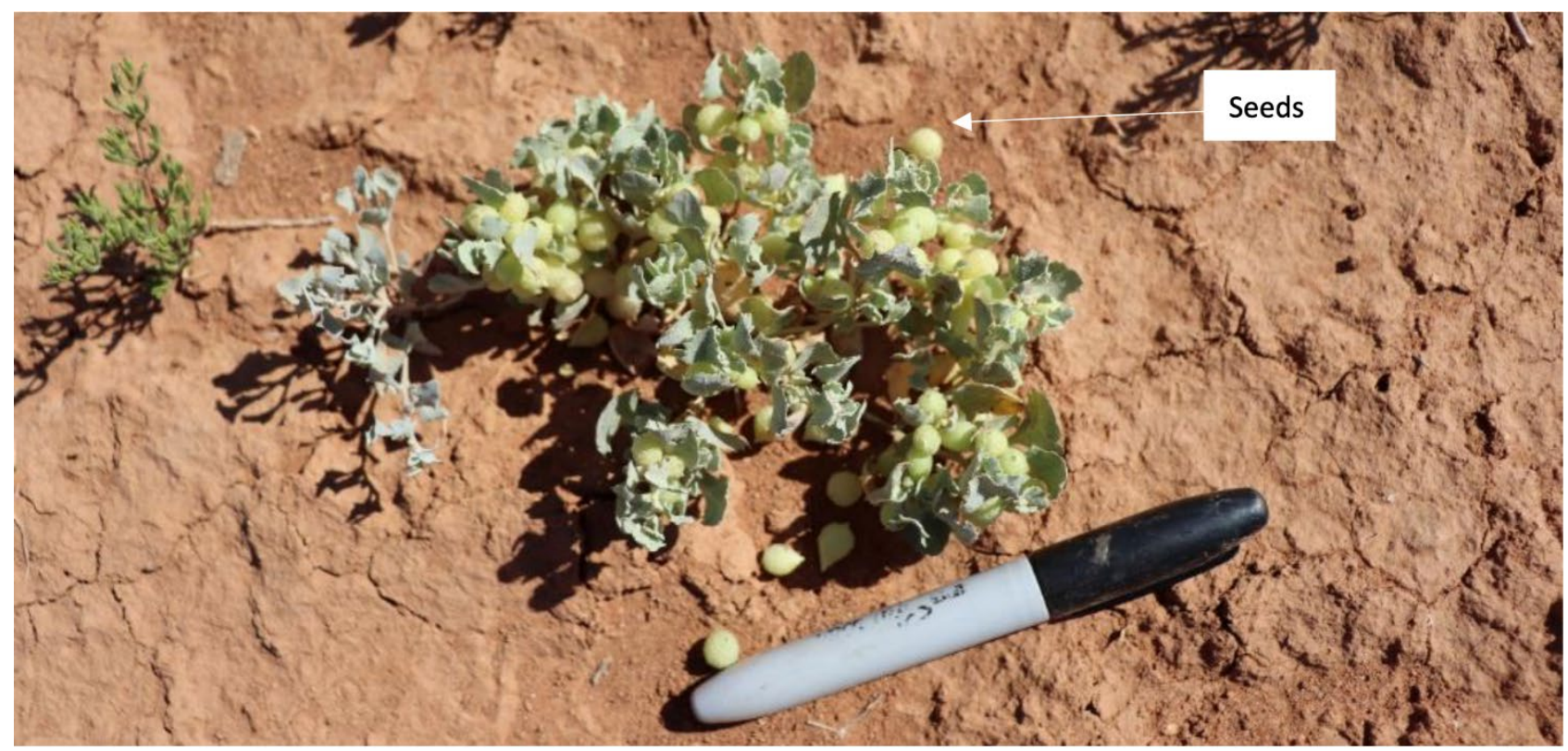

Figure 4 Pop saltbush (Atriplex holocarpa) establishes rapidly and produces masses of seed within a month of germination, even small plants are reproductively active 


\section{$4 \quad$ Case study 1: Port Augusta ash storage area}

Background: The Port August Power Station closed in 2016, the site's ash storage area (ASA) covers 272 ha and is located on the city's edge (Figure 5). For its revegetation, soil was excavated from a borrow pit and spread to an average depth of $15 \mathrm{~cm}$. The site was then direct seeded using the 'ground up' methodology.

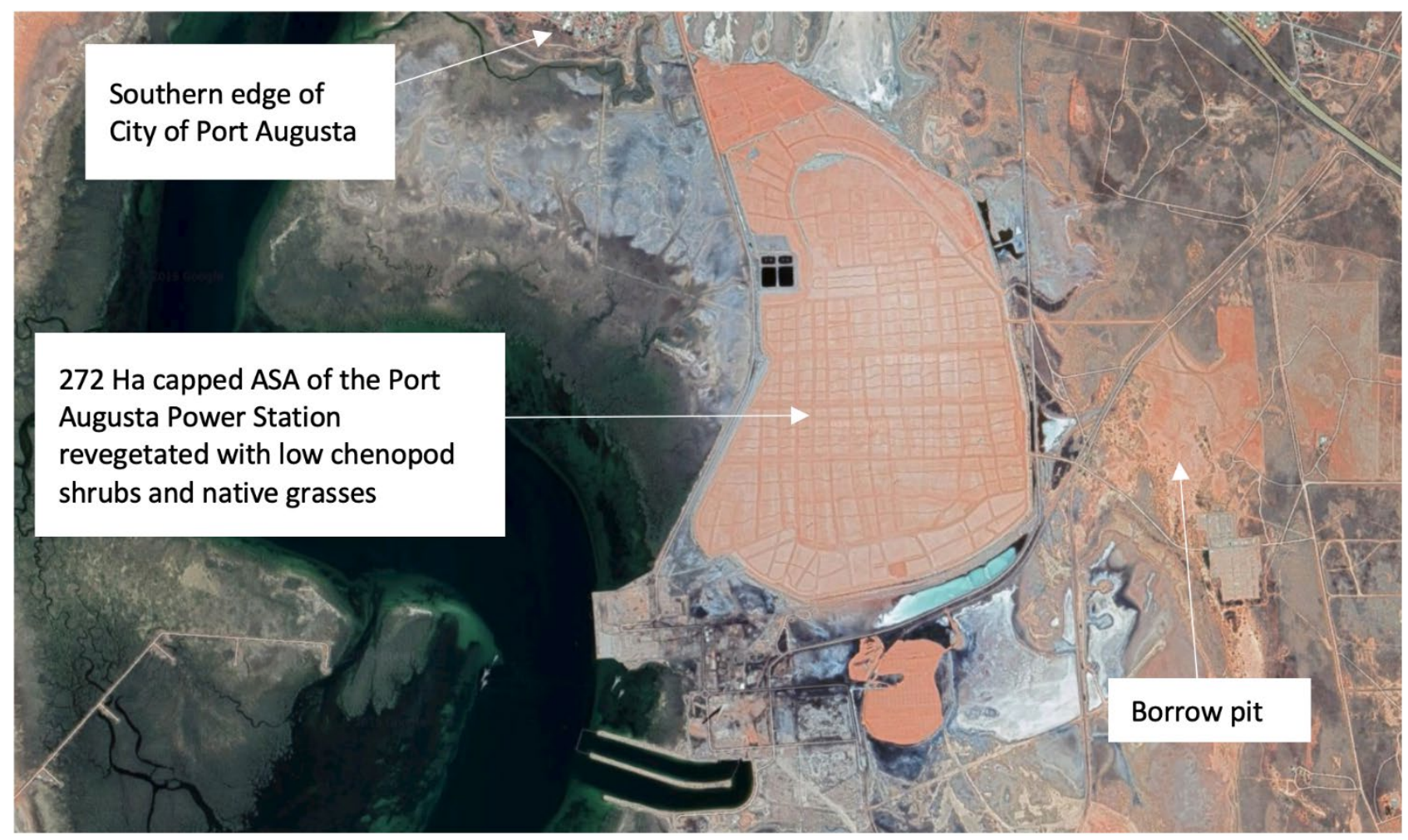

Figure 5 The 272 ha revegetation project of the ash storage area from the Port Augusta Power Station, which closed in 2016

Methodology: the seed mix comprised colonising species of low chenopod shrubs and grasses native to the area. A modified spreader and tractor were used to broadcast the seed, which was turned into the soil with a harrow. The average sowing rate of the entire ASA was 30 ha per day and occurred in 2017/2018. The flat topography of the ASA facilitated ease of access for this machinery, but some areas were also soddened and soft, precluding access of heavy machinery. These areas were hand seeded with the same density of seed, and the seed was turned into the soft soil using a Pistenbully and harrows. Monitoring of plant growth was conducted concurrently.

Outcomes: after two years of lower than average rainfall and just $0.8 \mathrm{~mm}$ recorded in the six weeks between monitoring in August and September 2018, survivability was 70\%. The average density of plants was 0.8 per $\mathrm{m}^{2}$ (counted within 90 survey quadrats) that, extrapolated for the entire site, represents over 2.2 million individual plants.

Based on tubestock methods, to establish this number of plants mechanically would take 2,176 hours, with labour and plant expenses ( $\$ 300$ per hour for 3 people and $\$ 2.30$ each respectively), the overall cost equates to more than $\$ 5.6$ million, but assumes $100 \%$ survivorship and no extra costs for watering. At $12 \%$ survivorship (Morgan 1999), more than 18 million plants would need to be planted in order to achieve the same results at a cost of $\$ 5$ million in labour and $\$ 41$ million in tubestock.

Clearly, the 'ground up' would be more successful than a 'top down' approach with equivalent expenditure. 


\section{$5 \quad$ Case study 2: Inkerman waste infill site}

Background: a 14 ha closed section of the Inkerman Waste Management site was capped for revegetation activities. The semi-arid site is located southeast of Port Wakefield, average annual rainfall is $330 \mathrm{~mm}$ (Commonwealth of Australia 2019).

Methodology: A 'ground up' approach to revegetation involved flooding the capped site with native grassland species. The site was hand seeded in 2013 and 2014 at $20 \mathrm{~kg}$ per ha, and the seed turned in with a powerrake to promote seed-soil contact and germination outcomes (i.e. Rotundo \& Aguiar 2005).

Outcomes: By 2015 a thick cover of native grasses occurred across the site and a soil crust had started developing; by 2019 the soil crust was thick; the grasses produced large numbers of seeds within a short period, such that the site became stable and self-sustaining (Figures 6 and 7).

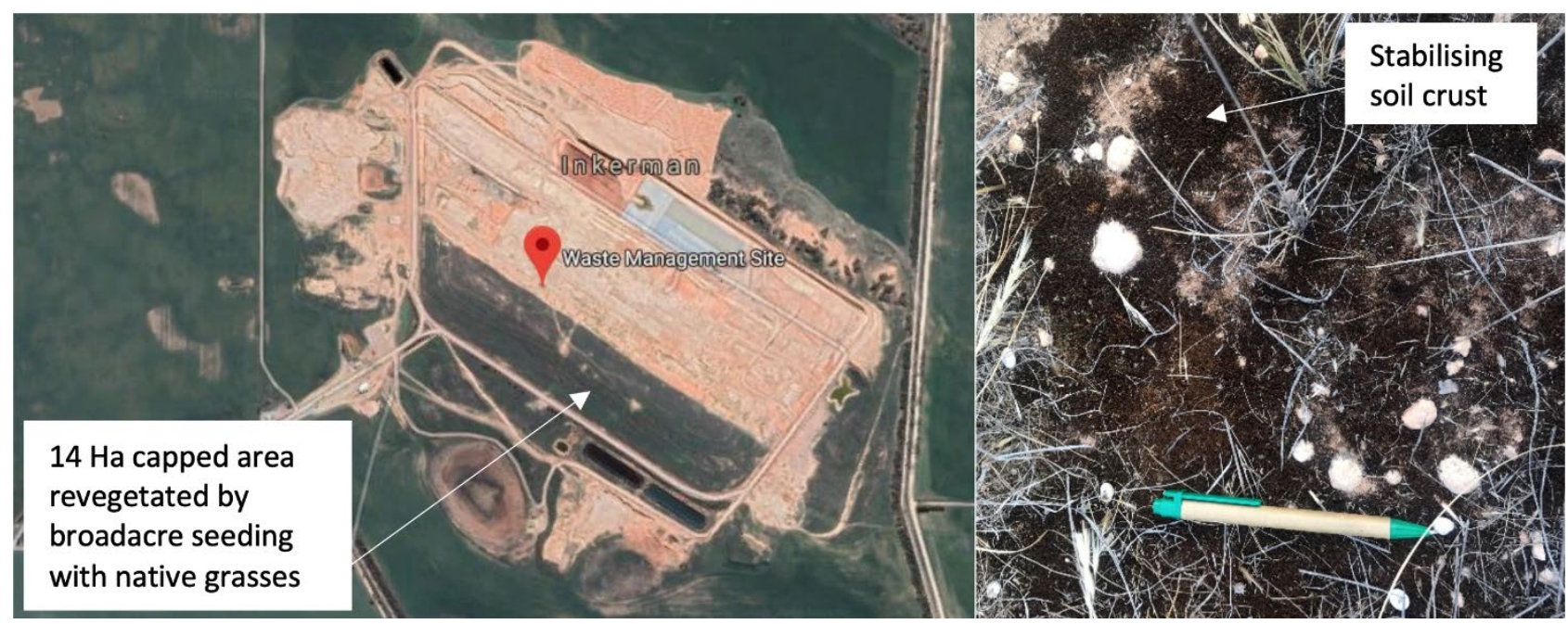

Figure 6 The 14 ha revegetation project of the Inkerman Waste Management site located $14 \mathrm{~km}$ southeast of Port Wakefield, South Australia (left); thick soil crust in 2019 (right)

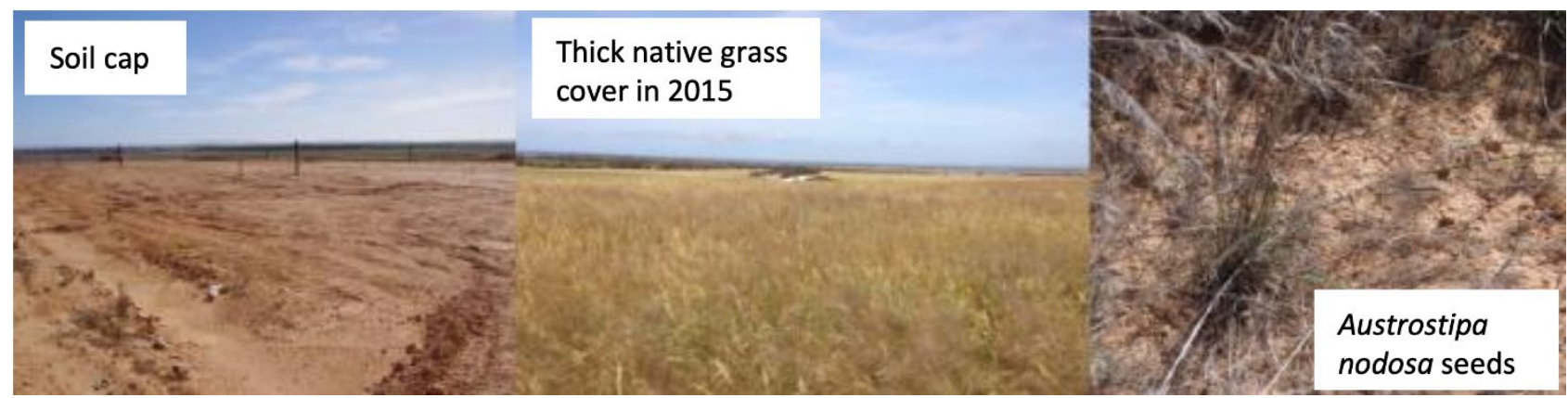

Figure 7 The soil cap, grass cover in 2015 and seed production of grass species (Austrostipa nodosa) at the Inkerman Waste Management revegetation site

\section{Case study 3: Monarto Zoo}

Background: A 14 ha area of land previously used for dryland cropping was designated for revegetation to extend the adjacent native vegetation area. A declared weed (horehound, Marrubium vulgare) occurred in high densities at the site; average annual rainfall is $403 \mathrm{~mm}$ (Commonwealth of Australia 2019).

Methodology: To reduce weed loads, the site was pre-treated with a control burn, two rounds of weed spraying and a light harrow. Direct seeding occurred in 2012 with the 'ground up' methodology; the site was flooded with the seed of colonising species at $15 \mathrm{~kg}$ per ha. A combination of mechanical and hand seeding was used to spread the seed (Figure 8). Small numbers of tubestock were also planted to promote a grassy woodland structure. 


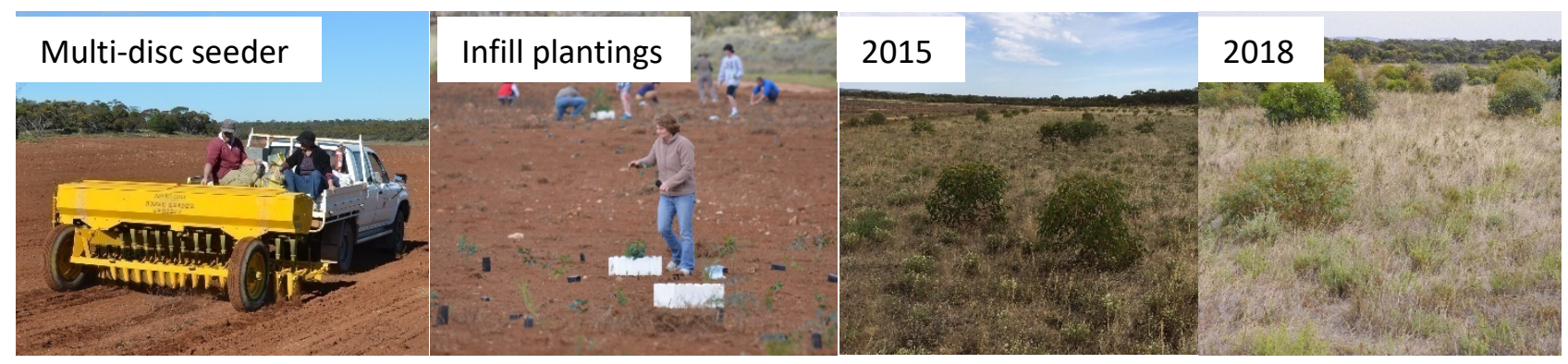

Figure 8 The multi-disc seeder, infill planting activity, growth in 2015 and growth in 2018 at the Monarto Zoo revegetation site

Outcomes: Within three years of direct seeding a thick cover of plants was evident at the site; germination rates of native plants exceeded 20 plants per $\mathrm{m}^{2}$; horehound had decreased by $98 \%$ from 4 plants per $\mathrm{m}^{2}$ to 0.1 plants per $\mathrm{m}^{2}$. Tubestock survival exceeded $70 \%$ with no watering or maintenance required.

\section{$7 \quad$ Case study 4: Dibharra}

Background: A 3 ha parcel of semi-arid land formally used for cropping was earmarked for revegetation to a native vegetation system and native seed orchard. Located near Moonta, South Australia, average annual rainfall is $370 \mathrm{~mm}$ (Commonwealth of Australia 2019).

Methodology: To reduce weed loads, the site was pre-treated with two rounds of weed spraying. Direct seeding occurred in August 2016 with a 'ground up' methodology; the site was flooded with the seed of colonising grass and chenopod species at $20 \mathrm{~kg}$ per ha.

Outcomes: Thick growth of 38 plants per $\mathrm{m}^{2}$ had occurred onsite within five months, and plants were reproductively active (Figure 9). This density of plants would equate to 1.14 million plants across the 3 ha.

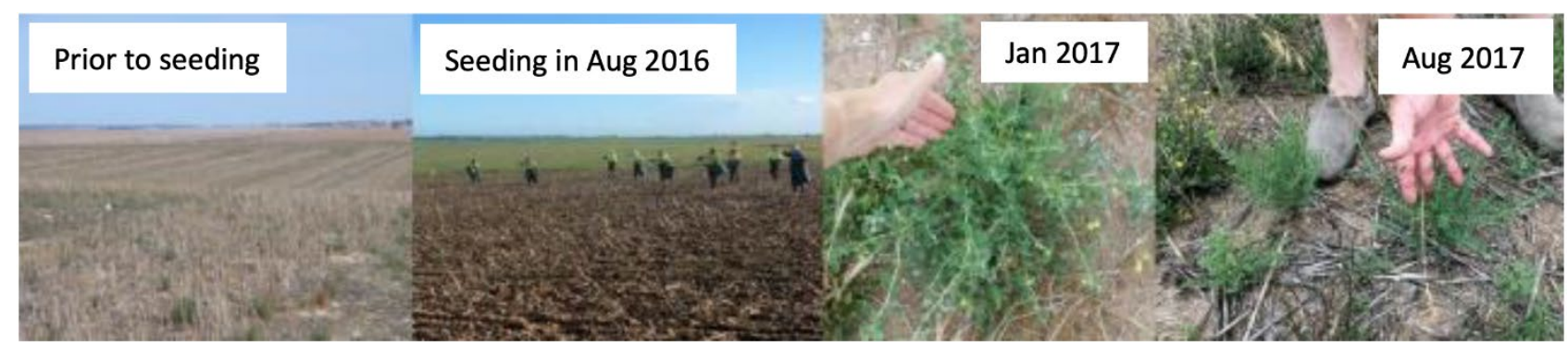

Figure 9 The Dibharra revegetation site prior to seeding, during seeding, and new growth in January and August 2017

\section{Discussion}

A broad range of revegetation methodologies, much broader than is covered in this analysis, are being used in the management of site closures. The aim of this study was to demonstrate the effectiveness of a 'ground up' approach for delivering revegetation outcomes in arid areas. In arid environments, natural systems and species exist that are already well adapted for harsh conditions and disturbance. These plants have evolved to survive with minimal rainfall and low nutrient soils, which can be highly alkaline and sodic. Native opportunistic plants in these areas take advantage of small amounts of rainfall to germinate, grow and reproduce; often developing within a very short time (weeks). A 'ground up' approach harnesses these natural assets and processes to fast-track mine site stabilisation and recovery.

The recovery services provided by colonising species include binding soil, reducing erosion, increasing rainfall infiltration, building seedbanks, producing leaf litter (organic carbon) and attracting invertebrates. Invertebrates then play important roles as soil engineers, pollinators and seed dispersers. Species selection is pivotal to catalysing these processes. While mid- to late-succession species are important in developing a 
healthy plant community in the long-term, these species can often be slow to establish, taking some time before providing recovery services. Meanwhile, colonising species will establish rapidly, beginning the process of building biological function. It would seem prudent to use colonisers at the start of restoration activities to boost stabilising and recovery processes, and outcomes.

The 'ground up' cropping methodology provides an effective system for covering large areas rapidly with a thick cover of diverse seeds. Seeds of suitable species will persist for extended periods within the soil until suitable conditions arise for germination. A broad range of machinery has been used for spreading native seed, mostly modified farm seeders. A key limitation to using traditional seeding machinery is a restriction in the type of seed that can be delivered. Typically, light and fluffy seeds such as grasses and seeds with highly variable sizes and shapes cannot be readily delivered. These sorts of seeds may be hand seeded or pelletised for distribution, but this approach requires additional costs and processes. A 'ground up' approach that uses a spreader provides the mechanism for broadcasting diverse seed mixes across large areas.

\section{Conclusion}

While mine site recovery in arid environments may seem a large task, it is important to understand that the natural environment already has adaptations and processes that can be harnessed to achieve the outcomes required. A 'ground up' approach provides a cost-effective and practical means to revegetation by selecting species that are already adapted to difficult and complex environments. The method can be applied at fineand broad-scales and provides low maintenance, self-sustaining, functional ecosystems that are resilient in arid environments.

\section{Acknowledgement}

We thank Phil Barron, Faith Coleman, Tom Gallasch, Tim Zwiersen, Terry Manning, Kym Maule and Travis Messner.

\section{References}

Australian Government 2019, '20 Million Trees Program', National Landcare Program, viewed 1 April 2019 , http://www.nrm.gov.au/national/20-million-trees

Bowman, D 2013, Restoration Won't Work: A New Way to Fix Old Mines, The Conversation, viewed 26 February 2018, https://theconversation.com/restoration-wont-work-a-new-way-to-fix-old-mines-21236

Carr, D, Bonney, N \& Millsom, D 2007, 'The effect of sowing season on the reliability of direct seeding', Rural Industries Research and Development Corporation, publication no. 07/105.

Clements, FE 1916, Plant Succession: Analysis of the Development of Vegetation, Carnegie Institution, Washington.

Commonwealth of Australia 2019, Climate Data Online, Bureau of Meteorology, viewed 27 February 2019, http://www.bom.gov.au

Crettenden, J 2013, 'Eyre Peninsula Farming Systems 2013 Summary', SARDI, Government of South Australia, viewed 1 April 2019 , https://pir.sa.gov.au/_data/assets/pdf_file/0006/219750/a._Introduction.pdf

Doley, D \& Audet, P 2013, 'Adopting novel ecosystems as suitable rehabilitation alternatives for former mine sites', Ecological Processes, vol. 2, pp. 1-11.

Environments by Design 2016, NRM Review and Price Guide for Significant Environmental Benefits, Government of South Australia, viewed 26 February 2019, https://www.environment.sa.gov.au/files/sharedassets/public/native_veg/seb-price-guide.pdf

Florabank 2019, Tubestock planting, Australian Government, Greening Australia and CSIRO, viewed 20 March 2019 , http://www.florabank.org.au/default.asp?V_DOC_ID=977

Government of South Australia 2011, 'Direct seeding - Natural Resources SA', Fact Sheet no. 4, viewed 1 April 20-19, https://www.naturalresources.sa.gov.au/files/554f0ccf-2c5b-4764-8d53-a31c00a1727f/sustainable-agriculture-directseeding-fact.pdf

Government of Western Australia 2019, Pearl bluebush, Department of Primary Industries and Regions, viewed 21 March 2019, https://www.agric.wa.gov.au/rangelands/pearl-bluebush

Haby, NA 2017, 'Long-term revegetation success of severely degraded chenopod shrublands', The Rangeland Journal, vol. 39, pp. 341-354.

Kent, K, Earl, G, Mullins, B, Lunt, I \& Webster, R 2002, Native Vegetation Guide for the Riverina: Notes for Land Managers on its Management and Revegetation, Charles Sturt University, Bathrust.

Lance, S 2015, Revegetation Research in the Murray Mallee - Improving the Success of Revegetation for Biodiversity and Habitat Restoration, South Australian Murray-Darling Basin Natural Resources Management Board, Government of South Australia. 
Lange, R \& Purdie, R 1976, 'Western myall (Acacia sowdenii), its survival prospects and management needs', Australian Rangeland Journal, vol. 1, pp. 64-49.

Morgan, JW 1999, 'Have tubestock plantings successfully established populations of rare grassland species into reintroduction sites in western Victoria?', Biological Conservation, vol. 89, pp. 235-243.

Natural Resources South Australia 2019a, 'Bucks for Bush, Direct seeding: Fact Sheet 5', viewed 1 April 2019, https://www.naturalresources.sa.gov.au/southeast/get-involved/grants-and-funding

Natural Resources South Australia 2019b, 'Bucks for Bush, Revegetation Planting: Fact Sheet 4', viewed 1 April 2019, https://www.naturalresources.sa.gov.au/southeast/get-involved/grants-and-funding

Nicholas, PWB, Morris, CE \& Keith, DA 2010, 'Testing a facilitation model for ecosystem restoration: does tree planting restore ground layer species in a grassy woodland?', Austral Ecology, vol. 35, pp. 888-897.

Palma, AC \& Laurance, SGW 2015, 'A review of the use of direct seeding and seedling plantings in restoration: what do we know and where should we go?', Applied Vegetation Science, vol. 18, pp. 561-568.

Piggot, JP, Brown, PH \& Williams, MM 1987, 'Direct seeding trees on farmland in the Western Australian wheatbelt', Department of Agriculture and Food, Western Australia, report 146.

Rotundo, JL \& Aguiar, MR 2005, 'Litter effects on plant regeneration in arid lands: a complex balance between seed retention, seed longevity and soil-seed contact', Journal of Ecology, vol. 93, pp. 829-838.

Standards Reference Group (SER) 2017, 'National Standards for the Practice of Ecological Restoration in Australia', Society for Ecological Restoration Australasia (SERA), Australia.

Succession Ecology 2018, Post Seeding Monitoring: June 2018 Assessment, Succession Ecology and Flinders Power, report ES1118, Adelaide.

Trees for Life (TFL) 2019, Direct Seeding, viewed 1 April 2019, https://treesforlife.org.au/direct-seeding 